Sekilas Tentang Temuan Ribuan Koin Belanda di Desa Mandala,

Kecamatan Telaga Langsat, Kabupaten Hulu Sungai Selatan 106-116

\title{
SEKILAS TENTANG TEMUAN RIBUAN KOIN BELANDA DI DESA MANDALA, KECAMATAN TELAGA LANGSAT, KABUPATEN HULU SUNGAI SELATAN
}

\author{
Bambang Sugiyanto* \\ Balai Arkeologi Banjarmasin, Jalan Gotong Royong II, RT 03/06, Banjarbaru 70711, Kalimantan Selatan; \\ Telepon (0511) 4781716; Facsimile (0511) 4781716
}

Artikel masuk pada 14 Februari 2012

Artikel selesai disunting pada 23 September 2012

\begin{abstract}
Abstrak. Tulisan ini membahas temuan koin Belanda yang ditemukan dalam tempayan gerabah kecil oleh penduduk Desa Mandala di bantaran Sungai Mandala. Studi kedua temuan tersebut bersifat kualitatif, didukung oleh studi pustaka tentang sejarah Kesultanan Banjar dan okupasi Belanda di kawasan tenggara Kalimantan. Analisis morfologis menunjukkan bahwa koin Belanda tersebut berasal dari abad ke-17 sampai ke-18 Masehi, sedangkan tempayan gerabah merupakan buatan lokal. Keberadaan koin di bantaran Sungai Mandala tersebut diduga berhubungan erat dengan kegiatan perdagangan intensif yang terjadi di Daerah Aliran Sungai Mandala pada masa lampau.
\end{abstract}

Kata kunci: koin Belanda, gerabah, Sungai Mandala, transportasi air, perdagangan, okupasi Belanda, Kesultanan Banjar

Abstract. DISCOVERY OF DUTCH COINS ON THE MANDALA RIVERBANK, HULU SUNGAI SELATAN DISTRICT. This paper discusses the findings of the Dutch coins inside a small pottery jar by the Mandala villagers on the banks of the Mandala River. Both artefacts were studied by qualitative analysis supported by literature study on the history of the Sultanate of Banjarmasin and Dutch occupying the southeastern region of Kalimantan. Morphological analysis showed that the Dutch coins are dated from the 17th to 18th century, while the earthenware was locally made. The existence of coins in the Mandala riverbank suggests the occurrence of intensive trading activities in the Mandala River Basin.

Keywords: Dutch coins, pottery, Mandala River, water transportation, trade, Dutch occupation, Sultanate of Banjar

\section{A. Pendahuluan}

Riwayat temuan berasal dari hasil penemuan seorang penduduk Desa Mandala RT.2 RK.I, Kecamatan Telaga Langsat, Kabupaten Hulu Sungai Selatan, bernama
Bapak Gumri (45 tahun). Awalnya Gumri yang berprofesi sebagai nelayan pencari ikan, sedang menyusuri Sungai Mandala dalam rangka mencari ikan. Kegiatan ini dilakukan dengan menggunakan semacam tombak

\footnotetext{
* Penulis adalah Peneliti Madya pada Balai Arkeologi Banjarmasin, email: iyan_balar_bjb@yahoo.com
} 
Sekilas Tentang Temuan Ribuan Koin Belanda di Desa Mandala,

Kecamatan Telaga Langsat, Kabupaten Hulu Sungai Selatan 106-116

yang cukup panjang untuk mematikan ikan yang ditangkap. Hari itu, secara tidak sengaja tombaknya menyentuh sesuatu yang menimbulkan kecurigaan, ada bunyi barang pecah dan gemerincing suara logam.

Kemudian Gumri mulai mencari jawaban apa yang ada di lokasi itu, dengan meraba langsung pada lokasi yang dimaksud. Ternyata hasilnya cukup mengejutkan, yaitu terdapat sebuah tempayan gerabah kecil yang telah pecah dan ribuan koin logam kuna yang kemungkinan ada dalam tempayan tersebut. Peristiwa tersebut terjadi pada tanggal 9 Mei 2011 tepatnya pada pukul 14.00 WITA. Temuan ini segera menggemparkan kalangan masyarakat di sekitar lokasi temuan, bahkan langsung menjadi berita dalam sebuah harian lokal di Banjarmasin. Dalam berita tersebut ditulis bahwa jumlah koin itu ada sekitar 1.170 buah koin yang berangka tahun sekitar 1800 - 1900 Masehi. Tulisan yang ada pada koin-koin itu menunjukkan dengan jelas asalnya, yaitu sebagai mata uang logam pada zaman penjajahan Belanda di Indonesia.

Temuan tersebut segera ditindaklanjuti oleh Dinas Kebudayaan dan Pariwisata Kabupaten Hulu Sungai Selatan, yang beralamat di Jalan Jenderal Sudirman No. 26 Kandangan, dengan mengirimkan surat permohonan penelitian dan pendataan selanjutnya kepada Balai Arkeologi Banjarmasin dan Museum Lambung Mangkurat Banjarbaru bernomor No. 430/ 146/Disbudpar tertanggal 11 Mei 2011. Berdasarkan surat tersebut, tim kerjasama Balai Arkeologi Banjarmasin dan Museum Lambung Mangkurat Banjarbaru kemudian mengadakan penelitian dan pendataan terhadap temuan koin kuna peninggalan Belanda tersebut.

\section{B. Objek Penelitian}

Objek penelitian yang dimaksud adalah artefak yang ditemukan oleh Bapak Gumri pada tanggal 9 Mei 2011, di dasar Sungai Mandala (Foto 1). Secara umum, temuan Gumri tersebut dapat dibagi dalam dua kelompok. Kelompok pertama adalah wadah yang berasal dari tanah liat bakar berupa tempayan gerabah kecil yang dipakai sebagai wadah koin itu, dan kelompok kedua adalah himpunan koin yang ditemukan di dalamnya.

Secara morfologi, tempayan gerabah yang dipakai sebagai wadah koin itu mempunyai bentuk yang cukup kecil, tidak tebal, dengan permukaan cukup halus, dan hanya mempunyai pola hias di bagian leher dan bibir wadah. Sepintas bentuknya hampir sama dengan wadah gerabah yang ditemukan di Situs Benteng Tabanio.

Sementara untuk koinnya sendiri, berdasarkan pengamatan langsung dapat dikelompokkan dalam tiga kelompok, yaitu: koin dengan tulisan VOC (Foto 4), koin dengan tulisan Indie Batavia (Foto 2), dan koin dengan tulisan Nederlands Indie (Foto 3). Dari ketiganya, terdapat tiga buah bentuk koin, yaitu koin kecil, koin sedang, dan koin besar. Ada beberapa koin yang di antaranya mempunyai bentuk yang unik dan menarik. Mereka tidak mempunyai bentuk yang bulat pipih rata, tetapi mempunyai sisi yang terpotong, tampaknya disengaja karena bentuk potongan yang rapi dan bagus.

Koin bertulis VOC antara lain berangka tahun 1730, 1733, 1746, 1751, 1754, 1766, 1767, 1776, 1777, 1778, 1779, 1784, 1785, 1786, 1787, 1788, 1790, 1791, 1792, 1792, 1793 , dan 1797. Koin yang bertulis Indie Batavia berangka tahun 1802, 1803, 1805 , 1807, 1815, 1816, 1819, 1820, 1821, dan 
Sekilas Tentang Temuan Ribuan Koin Belanda di Desa Mandala, Kecamatan Telaga Langsat, Kabupaten Hulu Sungai Selatan 106-116

1822. Koin yang bertulis Nederland Indie berangka tahun $1823,1824,1825,1826,1833$, 1834, 1836, 1837, 1838, 1839, 1840, dan 1858.

Tampaknya ada keberlanjutan proses pembuatan koin pada masa sekitar 1800 sampai awal 1900. Bisa dikatakan hampir setiap tahun pemerintah Belanda mengeluarkan bentuk mata uang koin lain, dengan besaran yang berbeda. Angka tahun yang tertera dalam koin kuna tersebut menunjukkan kecenderungan seperti itu.

Keberadaan koin pemerintahan kolonial Belanda ini dapat digunakan sebagai data penentuan kronologi sejarah yang berkaitan erat dengan perdagangan dan perekonomian pada masa lalu. Studi tentang jenis mata uang yang pernah beredar ini biasa disebut dengan Numismatik, dengan penekanan pada penelitian tentang sejarah tentang awal munculnya mata uang, cara pembuatan, lokasi pembuatan, perusahaan atau pemerintah yang membuat, variasi dan jenis mata uang, sejarah politik yang melatarbelakangi pembuatan mata uang, dan tentang pemalsuan-pemalsuan yang terjadi.

Secara umum, berdasarkan data keberadaan mata uang di wilayah Indonesia sudah dikenal pada masa Kerajaan Mataram Hindu. Pada masa-masa yang lebih tua, kegiatan perdagangan dilakukan dengan sistem barter atau pertukaran barang langsung. Sistem perdagangan ini tidak memerlukan mata uang dalam transaksi perdagangannya. Sistem perdagangan ini lambat laun terkikis, meski di beberapa tempat masih dilakukan sampai sekarang. Kemajuan teknologi dan ilmu pengetahuan membuat manusia mampu membuat dan mencetak mata uang baik yang berbahan logam maupun kertas. Oleh karena itu, peran mata uang ini sangat penting dalam mengungkapkan sejarah perdagangan dan ekonomi serta politik pada masa berlakunya.

\section{Pembahasan}

Koin buatan pemerintah kolonial Belanda memang sangat sering kita dapatkan di hampir seluruh pelosok wilayah Indonesia, karena memang mereka sangat lama menjajah negara kita selama hampir 350 tahun. Tentunya bukan sesuatu yang mengherankan jika di suatu lokasi di wilayah negara Indonesia ini ditemukan koin Belanda lama (gulden). Koin itu memang pernah digunakan di Indonesia yang masa itu masih bernama Nusantara dengan beberapa negara kerajaan yang besar dan banyak sekali kerajaan kecil lainnya. Sifat monopoli di segala bidang yang diterapkan oleh VOC, yang kemudian dilanjutkan oleh pemerintah Kerajaan Belanda menyebabkan semakin meluasnya peredaran dan distribusi koin logam ini ke seluruh pelosok Nusantara.

Lokasi temuan yang berada di wilayah Kabupaten Hulu Sungai Tengah, Provinsi Kalimantan Selatan, juga pernah menjadi daerah jajahan (koloni) Belanda pada masa Ialu. Seperti diketahui, jika Kerajaan Banjarmasin dapat diduduki oleh Belanda pada tanggal 11 Juni 1860. Dalam konteks ini, yang menarik adalah ribuan koin yang ditemukan di Desa Mandala, semuanya mempunyai angka tahun pembuatan sebelum tahun resmi penaklukan Kerajaan Banjarmasin, yaitu dari tahun 1730 sampai 1858. Dua tahun sebelum kejadian tersebut di atas, dapat dikatakan sebagai masa-masa yang sangat rawan bagi kelangsungan hidup Kerajaan Banjarmasin. Pertikaian antara kelompok dan keluarga kerajaan tentang perebutan hak dalam memerintah kerajaan, 
Sekilas Tentang Temuan Ribuan Koin Belanda di Desa Mandala,

Kecamatan Telaga Langsat, Kabupaten Hulu Sungai Selatan 106-116

dimanfaatkan dengan sangat baik oleh pemerintah kolonial Belanda untuk dapat menduduki dan menaklukan Kerajaan Banjarmasin. Latar belakang keperluan akan batubara membuat Belanda sangat berambisi menguasai wilayah Kalimantan, yang sangat kaya akan tambang batubara tersebut. Pembukaan tambang batubara yang ada di Pengaron, merupakan salah satu bukti kuat tentang ambisi Belanda tersebut. Pembangunan tambang batubara Pengaron ini juga yang akhirnya menyulut perang besar antara Belanda dengan masyarakat Kalimantan Selatan yang dipimpin oleh Pangeran Antasari.

Perang Banjar berakhir dengan kemenangan Belanda, yang imbasnya adalah pembubaran Kerajaan Banjarmasin oleh pemerintah kolonial Belanda pada tahun 1860. Sejak saat itu, wilayah Banjarmasin dan sekitarnya menjadi jajahan (koloni) Belanda dan tentunya akan membuat peredaran mata uang Belanda semakin marak sesuai dengan perkembangan perdagangan dan perekonomian yang terjadi.

Keberadaan koin kuna peninggalan Belanda (mulai dari VOC sampai pemerintahan kolonial Belanda), menunjukkan gambaran bahwa peredaran koin itu sudah merambah wilayah Kabupaten Hulu Sungai Selatan. Peredaran koin ini menunjukkan bahwa kegiatan perdagangan di wilayah Kalimantan Selatan pada umumnya sudah menggunakan mata uang Belanda sebagai alat tukar dan jual beli. Uang koin itu memang sengaja disimpan oleh seseorang saudagar atau pedagang yang dulu pernah tinggal atau berdagang di sekitar lokasi temuan. Penemuan koin di Sungai Mandala itu menunjukkan bahwa pada masa berlakunya koin tersebut, kondisi Sungai Mandala sangat penting dalam kehidupan masyarakat. Kegiatan perdagangan yang dilakukan dan peredaran uang koin sangat mungkin dilakukan di sepanjang aliran Sungai Mandala ini. Uang koin itu dikumpulkan dan disimpan dalam sebuah tempayan gerabah kecil yang mudah dipindah-pindahkan. Kondisi yang "moveable" inilah yang kemudian sampai ke tangan penemu, yakni Gumri di dasar sungai Mandala. Bisa jadi kapal yang digunakan karam sehingga tempayan yang berisi kumpulan koin tersebut jatuh di dasar sungai.

Hal yang perlu diperhatikan dari temuan tersebut adalah kemungkinan "adanya koin palsu" di antara koin-koin kuna yang tersebut. Berdasarkan studi pustaka, diketahui jika pada masa lalu juga terdapat kegiatan pembuatan uang koin palsu. Beberapa kelompok pada masa itu, telah berusaha untuk membuat dan mencetak koin logam yang lain dari yang resmi dikeluarkan oleh pemerintah kolonial Belanda, mulai dari VOC sampai ke Nederland Indie. Bentuk koin palsu ini secara umum langsung dapat dilihat dengan "mata telanjang", karena memang terlihat berbeda dan sangat tidak sempurna bentuknya (Foto 5 dan 6).

Pemalsuan uang ini tidak hanya terjadi pada mata uang logam (koin) saja, tetapi juga mata uang kertas yang dibuat oleh pemerintah Belanda. Kegiatan pemalsuan ini sedikit banyak mempengaruhi kondisi perekonomian pada masa itu, sehingga banyak mata uang yang ditarik dari peredaran.

Ada satu fase yang tidak bisa dilewatkan dalam sejarah koin mata uang di Indonesia, yaitu fase darurat. Pada 1796-1797, VOC mengalami kesulitan menyuplai uang (dalam pecahan-pecahan kecil) dengan jumlah yang cukup untuk keperluan transaksi. Situasi ini biasanya disebabkan kiriman uang dari Negeri 
Sekilas Tentang Temuan Ribuan Koin Belanda di Desa Mandala, Kecamatan Telaga Langsat, Kabupaten Hulu Sungai Selatan 106-116

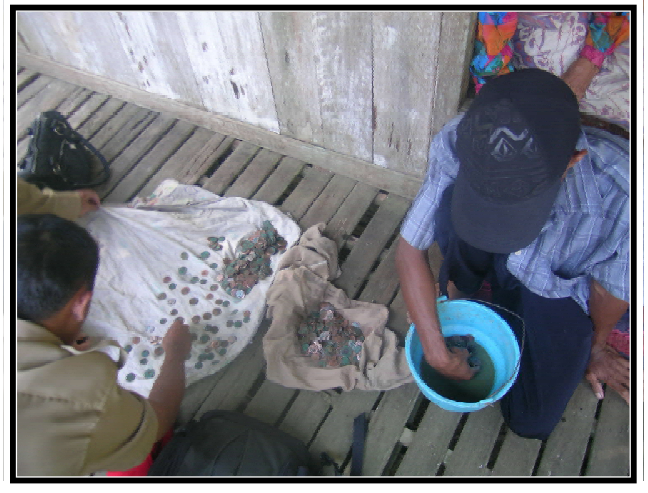

Foto 1. Foto koin kuno Belanda yang ditemukan oleh Bapak Gumri di Desa Mandala, Kabupaten Hulu Sungai Selatan

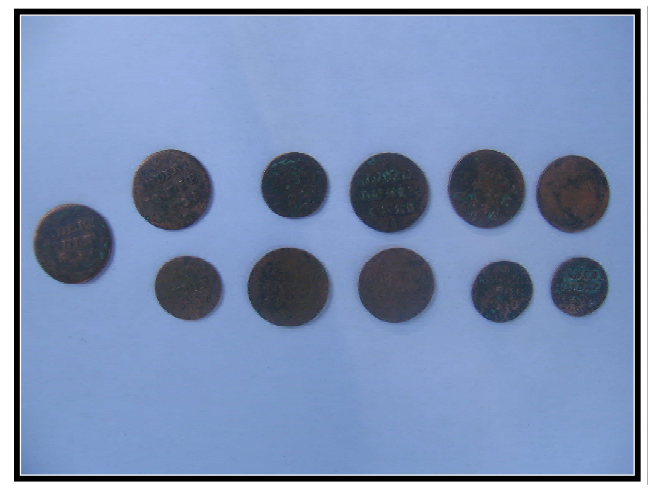

Foto 3. Koin Nederl Indie

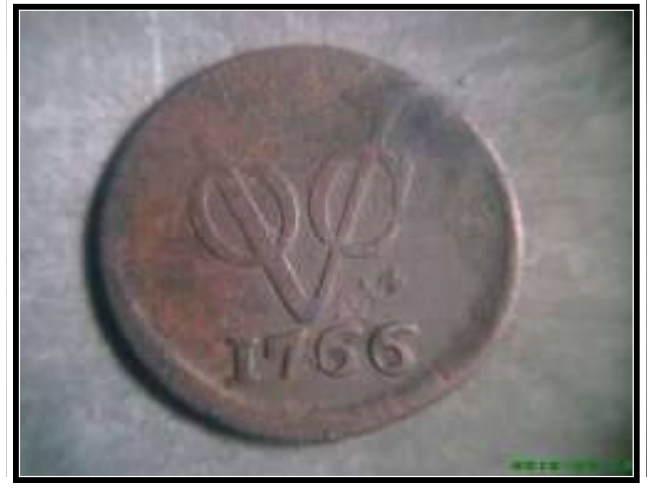

Foto 5. Contoh koin VOC yang cacat eror

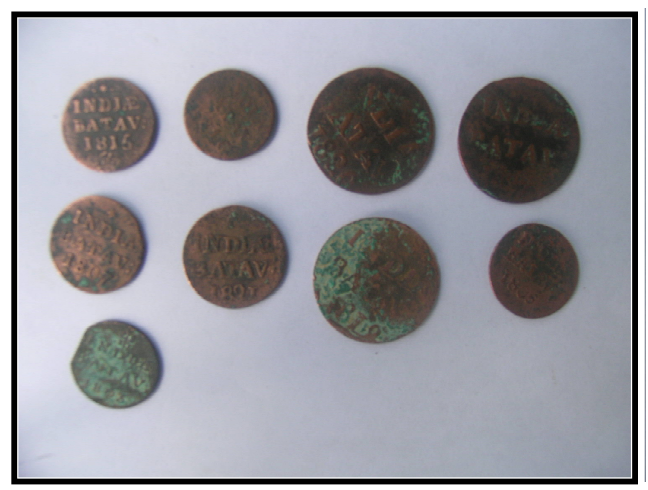

Foto 2. Koin Indie Batav

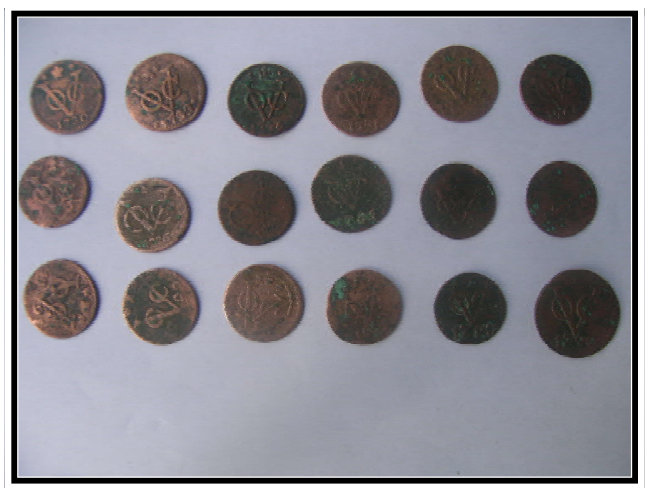

Foto 4. Koin VOC

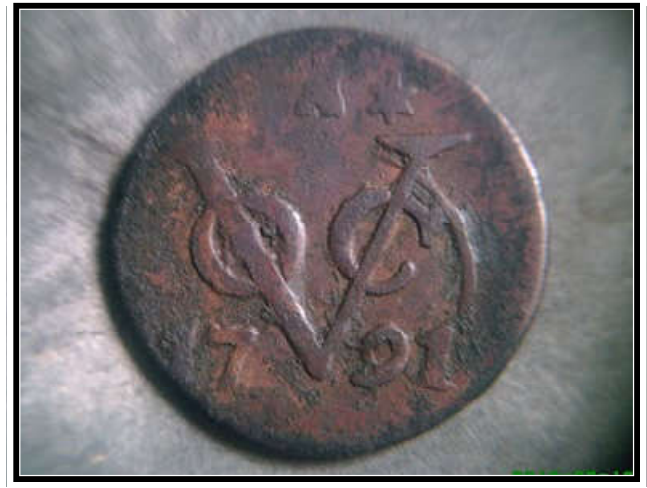

Foto 6. Contoh koin VOC yang cacat/eror 
Sekilas Tentang Temuan Ribuan Koin Belanda di Desa Mandala,

Kecamatan Telaga Langsat, Kabupaten Hulu Sungai Selatan 106-116

Belanda terlambat atau tidak sampai karena tenggelam dan masalah lain.

Pada saat yang sama, jung-jung Cina yang biasa menyuplai koin picis juga tidak berhasil merapat di pelabuhan-pelabuhan. Alasannya bisa bermacam-macam, dirompak di tengah laut atau tenggelam dihantam badai. VOC mengambil inisiatif dengan membuat uang darurat yang disebut bonk. Caranya dengan mendatangkan tembaga batangan dari Jepang, dipotong-potong, dan dicap di kedua sisinya. Berat setiap potong distandardisasi.

Biasanya, setiap pecahan bernilai setengah, satu, sampai dua stuiver untuk kalangan menengah ke atas. Sementara itu, untuk transaksi kecil digunakan uang-uang darurat dari timah. Pada kedua sisi uang tertera monogram $\mathrm{VOC}$ dan huruf $\mathrm{N}$ serta tertulis nilai uang dan tahun pembuatannya.

Uang dari timah bersifat lunak, sehingga gampang dipalsukan, dan VOC berisiko mengalami kerugian besar. Akibatnya, koin ini ditarik dari peredaran untuk dilebur kembali. Inilah yang menyebabkan koin era bonk menjadi sangat langka. Sebagai gantinya dibuat koin dari perunggu dan leburan meriam rusak yang dicampur timbal. Namun, periode bonk relatif berjalan singkat, yaitu sampai 1800 Masehi.

Sejarah koin di Indonesia dimulai pada akhir abad ke-16 Masehi ketika armada kapal dagang Belanda mendarat di Pulau Jawa. Pada tahun 1602 mereka mendirikan persekutuan dagang di Hindia-Timur, dikenal dengan nama VOC (Vereenigde Oost-Indische Compagnie) atau Kompeni Belanda. Tujuan mereka di Indonesia adalah merebut Sunda Kelapa untuk dijadikan pusat kegiatan kompeni. Sunda Kelapa kemudian diganti namanya menjadi Batavia. Belanda mulai menjalankan siasatnya yaitu mengusir orangorang Portugis dan merebut beberapa daerah pelabuhan penting bagi sektor perdagangan. Pada masa Kompeni Belanda, banyak beredar mata uang dengan berbagai satuan nilai seperti schelling, dukat, dukatoon, doit, stuiver, rijksdaalder, gulden, dan sebagainya. Mata uang tersebut dicetak di provinsi-provinsi di negeri Belanda dan Indonesia, terutama di Batavia.

Ketika Kompeni Belanda mengalami kesulitan memperoleh bahan baku logam untuk membuat mata uang, dicari alternatif lain untuk mencetak uang kertas yang menyerupai kertas berharga (sertifikat). Menjelang runtuhnya VOC (1799) dibuat semacam uang darurat dari potonganpotongan batangan tembaga berbentuk persegi empat yang dicetak di Batavia, disebut uang bonk.

Setelah VOC bubar, Indonesia di bawah kendali pemerintahan Republik Batavia (17991806), mengikuti situasi di Negeri Belanda, karena pada waktu itu pengaruh Revolusi Perancis (1789) sampai ke negara-negara Eropa, termasuk Belanda. Revolusi Perancis mengubah sistem monarki (kerajaan/ kekaisaran) menjadi republik. Mata uang keluaran masa ini dicirikan dengan tulisan "INDIFE BATAVORUM', dengan satuan nilai gulden dan stuiver.

Kemudian, tahun 1806-1811 di Indonesia beredar uang logam yang dibubuhi tulisan inisial LN, demikian juga pada kertas-kertas berharga diberi cap bertulisan $\mathrm{LN}$, singkatan dari 'Louis Napoleon'. Louis Napoleon adalah 
adik kaisar Perancis, Napoleon Bonaparte, yang amat terkenal dalam sejarah Perancis. la diangkat oleh kaisar menjadi raja di Belanda. Oleh karena itu, tidak mengherankan kalau mata uang keluaran masa ini menampilkan wajah Louis Napoleon, baik yang berlaku di Belanda maupun Indonesia. Satuan nilainya adalah gulden, rijksdaalder, doit, dan stuiver.

Pada masa pemerintahan Inggris di Indonesia, khususnya di Jawa (1811-1816), beredar berbagai macam mata uang yang dibuat dari emas, perak, tembaga, dan timah. Salah satu yang dikenal adalah 'Rupee Jawa' yang pada kedua sisinya tertera tulisan huruf Jawa dan Arab.

Jauh sebelum ini, mata uang Kompeni Inggris dengan monogram UEIC (United East India Company) telah beredar di daerahdaerah di Sumatra, contohnya Bengkulu, sejak tahun 1783 dengan satuan nilai suku dan keping.

Masa pemerintahan Inggris di Jawa tidak berlangsung lama. Pada tahun 1816 pemerintahan diserahkan kembali kepada Kerajaan Belanda, dengan demikian Indonesia kembali menjadi jajahan Belanda yang pada waktu itu disebut Hindia-Belanda (Nederlandsch-Indië).

Pada masa itu pemerintah HindiaBelanda menghadapi berbagai perlawanan dari penguasa-penguasa lokal di Indonesia sehingga terjadilah perang, di antaranya adalah Perang Diponegoro (1825-1830) di Jawa Tengah, Perang Paderi (1821- 1837) di Sumatra Barat, dan Perang Aceh (1873-1903). Perang tersebut menelan biaya yang sangat besar, yang mengakibatkan kas keuangan negeri Belanda menjadi kosong.
Pemerintah Hindia-Belanda berusaha mengisi kas dengan berbagai cara, antara lain menjual beberapa lahan tanah kepada perusahaan partikelir (swasta) yang membuka usaha perkebunan. Pemilik perkebunan selain orang Belanda sendiri juga orang-orang asing seperti Cina, Arab, Jerman, Inggris, Perancis, dan Jepang. Mereka membuka usaha perkebunan teh, kopi, tembakau, tebu, dan karet yang tersebar di berbagai daerah seperti Jawa, Sumatra, dan Kalimantan. Untuk membayar gaji buruh yang bekerja di perkebunannya, mereka menciptakan uang yang disebut 'token perkebunan', semacam alat tukar yang hanya beredar dan berlaku di tempat tertentu, seperti token untuk perkebunan teh, token untuk perkebunan tembakau, dan sebagainya. Token perkebunan yang pernah beredar di Indonesia bentuknya sangat unik, ada yang berbentuk segitiga, segilima, segienam, bahkan berbentuk seperti mata. Bahannya selain logam dan kertas, juga dari bambu.

Cara lainnya, Belanda menciptakan "tanam paksa" atau kultuurstelsel, yaitu rakyat Indonesia dipaksa menanam tebu, kopi, karet, dan teh yang sangat laku di pasaran internasional. Dengan cara ini Belanda memperoleh pemasukan uang yang sangat besar, tetapi sebaliknya rakyat Indonesia sangat menderita.

Pada masa itu satuan mata uang yang beredar adalah gulden dan cent, dengan nilainilainya yang dikenal dengan istilah ringgit $\left(2 \frac{1}{2}\right.$ Gulden/Rupiah), suku (50 Sen), tali (25 Sen), ketip atau picis (10 Sen), kelip (5 Sen), dan benggol atau gobang ( $2 \frac{1}{2}$ Sen). Selain uang logam dicetak pula uang kertas keluaran De Javasche Bank yang merupakan bank 
Sekilas Tentang Temuan Ribuan Koin Belanda di Desa Mandala,

Kecamatan Telaga Langsat, Kabupaten Hulu Sungai Selatan 106-116

pertama yang berdiri di Indonesia pada abad ke-19 Masehi. De Jacasche Bank sekarang menjadi Bank Indonesia.

Pada pertengahan abad ke-20 Masehi, terjadi Perang Dunia II dan Jepang muncul sebagai kekuatan baru di Asia. Bala tentara Jepang menduduki wilayah Asia Timur dan Asia Tenggara. Pada tahun 1942, Jepang berhasil menduduki Indonesia, dalam waktu singkat pemerintah Hindia-Belanda dibuat bertekuk lutut di bawah tentara pendudukan Jepang. Pada masa itu uang kertas yang beredar pertama kali tertera tulisan dalam bahasa Belanda dengan satuan gulden, oleh karena itu disebut "Gulden Jepang". Ketika pemerintah pendudukan Jepang melarang penggunaan bahasa Belanda maka dibuatlah uang kertas dengan tulisan bahasa Indonesia dan Jepang (huruf Kanji) dengan satuan rupiah. Oleh karena itu uang ini disebut "Rupiah Jepang".

Kembali pada temuan mata uang logam (koin) dari zaman kolonial Belanda di sini, yang tampaknya merupakan kumpulan uang dari seorang pedagang atau saudagar yang ketika itu sering berdagang sampai ke wilayah Kabupaten Hulu Sungai Selatan, tepatnya di sekitar Sungai Mandala. Tempat penyimpanan koin berupa sebuah tempayan gerabah dengan bentuk yang lumayan bagus dihiasi motif dekorasi sederhana, memberikan gambaran bahwa pada masa tersebut industri gerabah juga berkembang pesat. Diperkirakan saudagar ini menggunakan perahu kecil atau jukung dalam melakukan aktivitas perdagangan. Dengan perahu, dia dapat sampai ke desa-desa kecil yang pada umumnya berada di sepanjang Sungai Mandala. Perkiraan ini didasarkan pada lokasi penemuan tempayan gerabah yang berisi ribuan mata uang logam (koin) zaman penjajahan Belanda.

Pada masa kolonial, situasi perdagangan memang lebih dominan melalui jalur sungai daripada jalur darat. Hal ini dikarenakan pada masa itu, jalan-jalan darat belum sebanyak yang ada sekarang. Oleh karena itu, sesuai dengan tradisi dan budaya Banjar, hampir semua kegiatan kehidupan masyarakat dilakukan di atas air, yakni di atas sungai, danau atau rawa-rawa. Kondisi lingkungan Kalimantan Selatan yang sebagian besar berair membuat masyarakat Banjar yang menetap di sini melakukan adaptasi yang selaras dan harmonis, yaitu dengan membuat dan membangun perumahan model panggung serta mempunyai kemampuan untuk membuat dan mempergunakan perahu (jukung) sebagai alat transportasi utama dalam kehidupan sehari-hari mereka. Dengan menggunakan jukung, masyarakat berhubungan dengan kelompok lain, berdagang, mencari ikan, atau kegiatan lain dengan mudah dan lebih cepat.

Latar belakang tradisi dan budaya Banjar di atas, sangat mempengaruhi kondisi perdagangan yang pernah terjadi pada masa lalu. Lokasi penemuan koin kuna Belanda, yakni Sungai Mandala, besar kemungkinan pada masa itu merupakan jalur sungai yang sangat penting dalam kehidupan masyarakat yang tinggal di desa-desa yang ada di sepanjang aliran sungainya. Dengan melalui Sungai Mandala ini, masyarakat dapat bepergian dan melakukan hubungan dengan kelompok masyarakat lainnya. Mereka juga dapat melakukan aktivitas jual beli dengan pedagang atau penjual yang datang dan pergi ke desa-desa mereka. Aktivitas perdagangan ini kemungkinan besar hanya berlangsung 
pada hari-hari tertentu saja, tidak setiap hari. Seperti yang sampai sekarang masih dapat kita saksikan di beberapa wilayah di Kalimantan Selatan, dengan tradisi hari pasar yang berbeda untuk tiap daerahnya. Tradisi pasar ini membuat perputaran uang dan barang dagangan merata di hampir seluruh wilayah, tanpa ada monopoli perdagangan.

Secara kuantitas, mata uang logam (koin) kuna Belanda yang ditemukan Gumri tersebut memang tidak menunjukkan jumlah yang besar. Jumlah uang yang mencapai ribuan buah ini hanya mungkin dimiliki oleh seorang pedagang biasa bukan seorang saudagar besar yang kaya raya. Asumsi ini didasarkan pada nilai uang dan kondisi sungai yang menjadi jalur utama perdagangan pada masa lalu. Nilai uang logam yang diproduksi oleh pemerintah kolonial Belanda pada masa lalu adalah dipergunakan untuk mencukupi keperluan masyarakat bawah dalam kegiatan perdagangan dan lainnya. Sementara mata uang yang mempunyai nilai nominal besar, pada umumnya berbentuk mata uang kertas. Memang ada satu atau dua produk mata uang logam yang sangat besar nilai nominalnya, yang terbuat dari bahan logam mulia seperti emas atau perak. Mata uang logam seperti ini pada umumnya hanya diproduksi dengan jumlah yang terbatas, sehingga sangat susah untuk mendapatkannya dan kecil sekali kemungkinannya untuk bisa menemukannya dalam kondisi seperti penemuan koin di Sungai Mandala tersebut.

\section{Kesimpulan}

Berdasarkan analisis dan pembahasan di atas, maka dapatlah disimpulkan untuk sementara bahwa penemuan koin Belanda kuna oleh Gumri di Sungai Mandala ini merupakan penemuan kumpulan koin yang cukup penting. Penemuan kumpulan koin kuna dalam tempayan gerabah ini menjadi bukti bahwa kegiatan perdagangan pada masa lalu di sepanjang Sungai Mandala sudah ramai. Sungai Mandala yang sekarang kondisi sudah menyempit, merupakan jalur perdagangan yang ramai dan penting pada sekitar abad 17-18 Masehi. Ramainya perdagangan di Sungai Mandala ini bisa terjadi karena dua faktor, pertama sungai itu merupakan jalur utama transportasi dan komunikasi antara masyarakat di sepanjang aliran sungai dengan masyarakat luar. Kedua, tradisi dan budaya masyarakat Banjar termasuk masyarakat yang tinggal di sepanjang aliran Sungai Mandala, yang mempunyai kemampuan beradaptasi yang baik dengan kondisi lingkungannya. Mereka dapat melakukan semua aktivitas kehidupan di atas air, termasuk aktivitas jual beli, sehingga tidaklah aneh jika akhirnya Sungai Mandala menjadi tempat yang sangat ramai dengan aktivitas perdagangan meski hanya pada hari-hari tertentu saja.

Aktivitas perdagangan yang ramai inilah yang kemudian meninggalkan jejak-jejaknya dan salah satunya adalah sekumpulan mata uang logam (koin) kuna Belanda di Sungai Mandala. Penemuan koin ini menunjukkan gambaran yang jelas pada kita semua, bahwa sungai baik yang besar maupun kecil mempunyai fungsi yang sangat penting bagi kehidupan manusia. Sungai-sungai ini bukan saja memberikan fasilitas air (bersih), tetapi juga memberikan penghidupan dengan sumber dayanya seperti beraneka jenis ikan yang dapat dikonsumsi, serta dapat digunakan sebagai sarana transportasi dan komunikasi antar penduduk. Melalui sungai masyarakat 
Sekilas Tentang Temuan Ribuan Koin Belanda di Desa Mandala,

Kecamatan Telaga Langsat, Kabupaten Hulu Sungai Selatan 106-116

dapat berhubungan dengan kelompok lain, melakukan perdagangan, mendapatkan hiburan, dan lainnya.

\section{E. Rekomendasi}

Rekomendasi yang bisa diajukan sehubungan dengan adanya penemuan mata uang logam (koin) kuna Belanda ini adalah sebagai berikut:

1. Penemuan itu memang merupakan penemuan biasa yang bisa terjadi pada lokasi lain di sepanjang aliran sungai yang banyak terdapat di wilayah Kalimantan Selatan. Oleh karena itu, perhatian terhadap situssitus pemukiman kuna yang ada perlu ditingkatkan lagi di tahun-tahun mendatang. Hal ini didasarkan pada kenyataan bahwa budaya Banjar itu sangat identik dengan sungai, sehingga besar kemungkinan penemuan seperti ini akan juga ada di tempat lain di sepanjang aliran sungai.

2. Untuk keperluan pelestarian, ada baiknya pihak Museum Lambung Mangkurat, Banjarbaru, mempunyai beberapa koin dari penemuan tersebut sebagai contoh dan koleksi yang dapat dipamerkan (jika memang belum ada koleksi koin di Museum).

3. Kegiatan penelusuran Sungai Mandala dan beberapa sungai lainnya yang diperkirakan mempunyai fungsi penting dalam sejarah kehidupan masyarakat Kalimantan Selatan, perlu ditingkatkan dalam rangka mengungkapkan pentingnya peranan sungai dalam kehidupan manusia. Hasil kegiatan ini dapat dipergunakan untuk meningkatkan apresiasi masyarakat yang sekarang kelihatannya sudah semakin berkurang dalam memandang sungai. Sungai-sungai di wilayah Kalimantan Selatan lambat tapi pasti semakin terpinggirkan oleh masyarakat Banjar sendiri. Orientasi budaya sungai mulai ditinggalkan dan beralih ke budaya darat dengan banyaknya pembangunan jalanjalan darat di wilayah Kalimantan Selatan. 


\section{Referensi}

Anonim. 2008. Penambang temukan ribuan keping uang VOC. Harian Solo Metro, 23 Oktober.

Anonim. Jejak perkembangan koin di Indonesia. Infokito.net

Harsono, Puji. 2009. Sejarah perkembangan mata uang Indonesia. Makalah dalam Seminar Numismatika: Sejarah Uang Kertas Indonesia. Bank Indonesia, 27 Oktober. . 2004. Merangkai sejarah dari koin China. Harian Kompas, 24 September.

Saleh, M. Idwar. 1983/1984. Sekilas mengenai daerah Banjar dan kebudayaan sungainya sampai akhir abad XIX. Proyek Pengembangan Permuseuman Kalimantan Selatan, Depdikbud, Banjarmasin.

. 1958. Banjarmasin, selayang pandang mengenai bangkitnya Kerajaan Banjarmasin, posisi, fungsi, dan artinya. Dalam Sejarah Indonesia Dalam Abad ke-17. Bandung: Balai Pendidikan Guru.

Tim Editor. 2003. Sejarah Banjar. Banjarmasin: Badan Penelitian dan Pengembangan Daerah Provinsi Kalimantan Selatan.

Tim Penelitian, 2011. Laporan peninjaun temuan uang Belanda di Desa Mandala RT 2 RW 3, Kecamatan Telaga Langsat, Kabupaten Hulu Sungai Selatan, Provinsi Kalimantan Selatan. Laporan Peninjauan. Banjarbaru: Balai Arkeologi Banjarmasin. Belum terbit.

Usman, A. Gazali, 1995. Kerajaan Banjar: sejarah perkembangan politik, ekonomi perdagangan, dan agama Islam. Banjarmasin: Lambung Mangkurat University Press. 1990. Kasultanan Banjar. Dalam Kalimantan Scientiae 9 (20). 